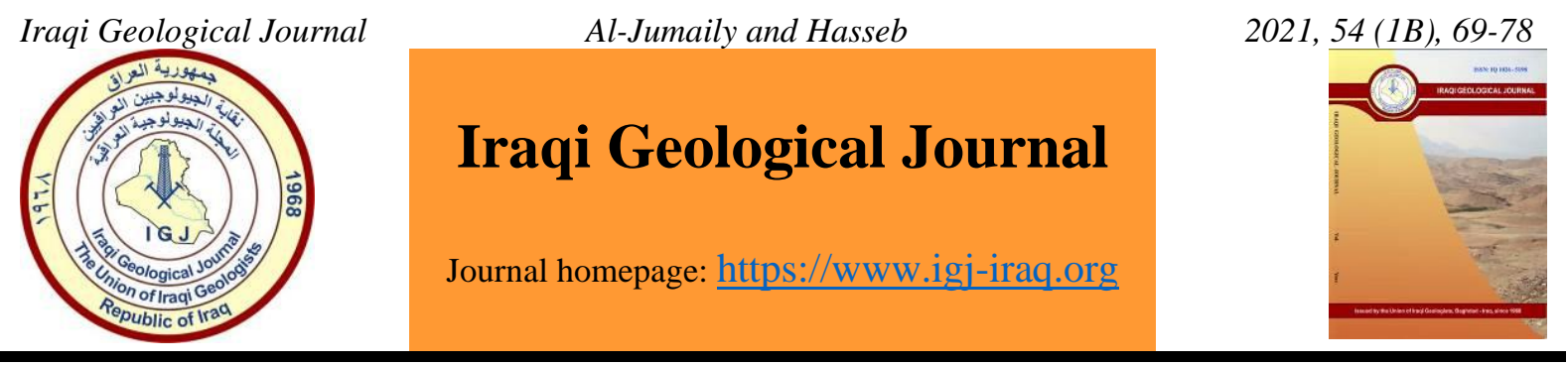

\title{
Impact of Oxides and Physiochemical Properties of Agricultural Soil on Bioaccumulation of Toxic Heavy Elements in Wheat Grains in Yaychi, Northeast of Iraq
}

\author{
Hassan Ahmed Ali Al-Jumaily ${ }^{1}$ and Dunya Najdat Hasseb ${ }^{1, *}$ \\ ${ }^{1}$ Department of Applied Geology, College of Science, Kirkuk University, Kirkuk, Iraq \\ *Correspondence: dunyanajdat3303@gmail.com
}

Received: 31 August 2020; Accepted: 8 December 2020; Published :28 February 2021

\begin{abstract}
To investigate the potential link between toxic heavy elements in soil with soil physiochemical properties and oxides, as well as their impact on the bioaccumulation of these elements in wheat grains. Agriculture soil and wheat grains were sampled from Yaychi area, Kirkuk northeast of Iraq. Soil physiochemical properties, oxides and toxic heavy elements contents were determined. The average concentration of toxic heavy elements in soil was in this order $\mathrm{Ni}>\mathrm{Cr}>\mathrm{Pb}>\mathrm{As}>\mathrm{Cd}>\mathrm{Hg}$, and some of these elements had exceeded their average in earth's crust and Canadian Agricultural Soil Quality Guidelines. While in wheat grains the toxic heavy elements, contents were in the following order $\mathrm{Cr}>\mathrm{Ni}>\mathrm{Pb}>\mathrm{As}>\mathrm{Cd}>\mathrm{Hg}$. The soil physiochemical properties in the study area are shown to be medium alkaline, non-saline, calcareous, non-gypsiferous, inorganic and loam texture. It became clear from the correlation matrix that the toxic heavy elements except for arsenic have significant relationships with different soil physiochemical properties and major oxides. In turn, oxides and the physiochemical properties of the soil and its type reduced the bioaccumulation of these elements in wheat grains except for arsenic, as appeared in the present study, that toxic heavy elements do not accumulate in wheat grains. And among the studied elements, arsenic had the highest bioaccumulation rate in wheat grains, because its concentration in soil has been affected by only human activities.
\end{abstract}

Keywords: Toxic; Agriculture; Soil; Oxides; Bioaccumulation

\section{Introduction}

Toxic heavy elements are considered one of the serious environmental contaminants (Nagajyoti et al. 2010). The main toxic heavy elements include arsenic, lead, mercury, cadmium, nickel and chromium (Friis, 2012; Tokar et al. 2013), they are toxic even in low concentrations and have the ability to bioaccumulate, this indicates that they may become harmful due to their entry into the food chain (Friis, 2012). The high soil content of heavy elements causes negative impacts on life forms and the environment due to their toxicity (Al-Jaberi et al. 2016). The reason for considering pollution and accumulation of toxic heavy elements as a significant problem is because of their plenty of different sources, toxicity, non-biodegradable characteristics, and tendency to accumulate (Hu et al. 2017). The bio-availability of elements in the soil is influenced by several factors including $\mathrm{pH}$ of the soil, the contents of organic matter; carbonates; clay minerals; iron, manganese, aluminum oxides as well as oxidation and reduction conditions (Alloway, 2005). Oxic conditions may lead to a release of elements DOI: 10.46717 igj.54.1B.6Ms-2021-02-24 
from organic matter, and they can also be released from carbonate and manganese-iron oxide due to the changes in $\mathrm{pH}$ and ionic composition (Al-Hamdani et al. 2016). The study area is constantly exposed to various pollutants by oil and industrial facilities, usage of chemical pesticides and fertilizers for agriculture purposes and from highways. As a result, toxic elements are added to agricultural soil and translocated into cultivated plants. Yaychi region is considered one of the important agricultural areas where various crops of cereals and vegetables are cultivated continuously and consumed by the population. the aim of this study is to identify the extent of toxic heavy elements translocation from agricultural soil to wheat grains, thus their bioaccumulation, and the role of the oxides and soil type and its different physiochemical properties in reducing bioaccumulation of these elements in wheat grains and therefore have knowledge whether these agricultural lands are suitable for planting wheat crop or not.

\section{Study Area Characteristics}

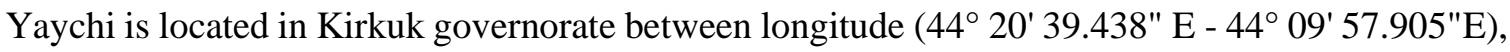
and latitude ( $\left.35^{\circ} 33^{\prime} 21.953^{\prime \prime} \mathrm{N}-35^{\circ} 18^{\prime} 41.585^{\prime \prime} \mathrm{N}\right)$ northeast of Iraq (Fig. 1). Tectonically, the study area is located within unstable shelf in the low folded zone which represented by Chamchamal-Erbil subzone (Al-Kadhimi et al., 1996). Structurally, the northeastern part of study area is composed of Kirkuk anticline (Baba Dome) and it is a convex fold with a reverse faulting in the area (Sissakian and Fouad, 2012). On the other hand, stratigraphically, the study area is covered with quaternary deposits, while tertiary deposits (represented by Fatha, Injana, Mukdadyia and Bai Hassan formations) are exposed in the northeast part of the study area within Kirkuk structure (Sissakian and Fouad, 2012).

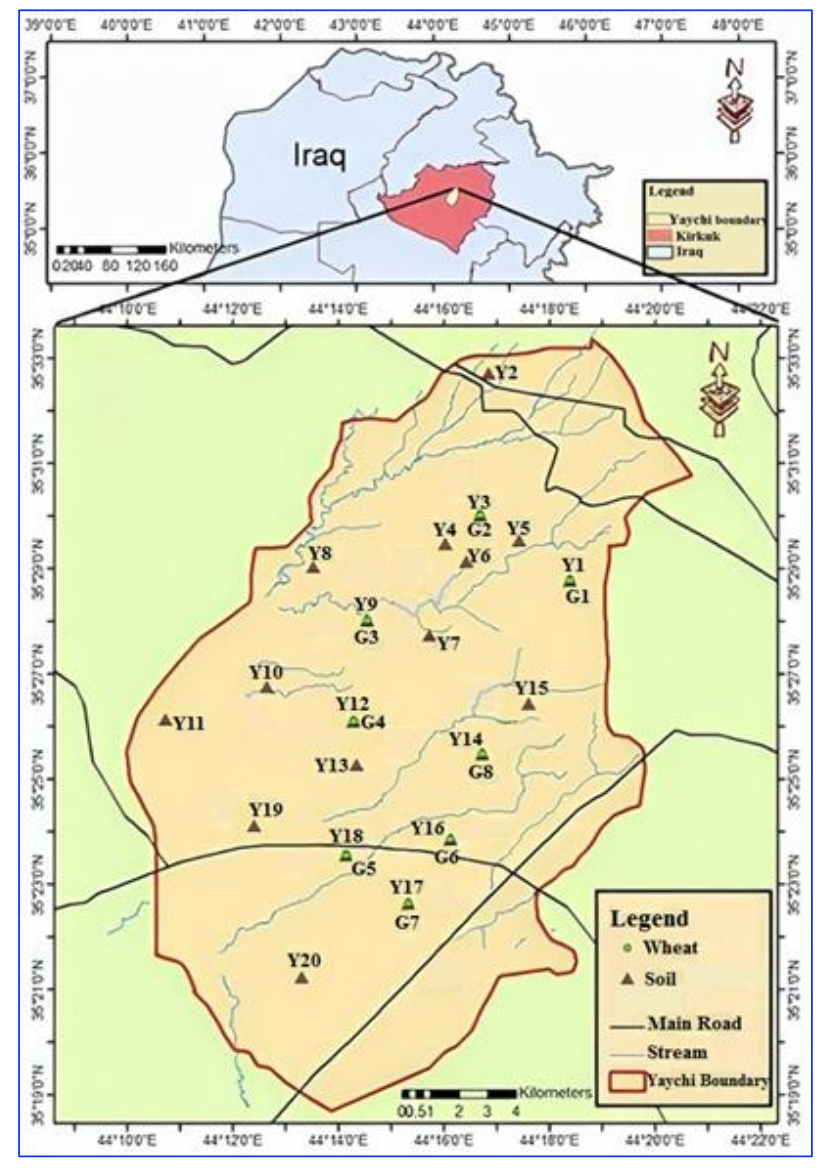

Fig. 1. Location map of the study area 


\section{Materials and Methods}

Soil and wheat samples were collected in a manner that covers the entire study area and focused on the areas near many sources of pollution. Twenty soil samples were collected using auger for depth of 0-20 cm. The soil samples were dried, all debris like stones (small gravel) and plants residues have been removed, then grinded with ceramic mortar and sieved through 200 mesh sieve and analyzed for its content of toxic heavy elements using modified aqua regia digestion $\left(1: 1: 1 \mathrm{HNO}_{3}: \mathrm{HCl}: \mathrm{H}_{2} \mathrm{O}\right)$ by ICPMS in Acme Lab in Vancouver, Canada._Soil properties (Calcium Carbonate $\mathrm{CaCO}_{3}$, Calcium Sulfate $\mathrm{CaSO}_{4} \cdot 2 \mathrm{H}_{2} \mathrm{O}$, Electrical Conductivity EC, Organic Matter OM) of these samples were analyzed in Kirkuk Agriculture Directorate Laboratories according to methods described as follows $\mathrm{CaCO}_{3}$ by Estefan et al. (2013), $\mathrm{CaSO}_{4} \cdot 2 \mathrm{H}_{2} \mathrm{O}, \mathrm{EC}$ by Richards (1954) and OM by Walkley (1947). While pH of soil was determined by preparing a suspended solution of calcium chloride $\left(\mathrm{CaCl}_{2}\right)$ as described by Whitehead (1973) in the Biochemistry Laboratory, Chemistry Department, Science Faculty, Kirkuk University. Size fraction analysis of soil samples was also performed as described (Carver, 1971; Folk, 1974). On the other hand, eight samples of wheat grain were collected from the same soil sampling sites in order to assess toxic heavy elements translocation, and analyzed for its content of these elements using aqua regia digestion method on the raw material by ICP-MS in Acme Lab in Vancouver, Canada.

\section{Results and Discussion}

\subsection{Soil Physiochemical Properties and Type}

Soil physiochemical properties can affect the bioavailability of toxic elements and their mobility in soil, so some of these properties have been studied (Table 1). Soil pH plays an important role in the movement and bioavailability of toxic heavy elements in soil. Between the basic and acidic soil solution, the movement of the toxic elements is less in the first because they are adsorbed on the surface of the basic soil more than the acidic soil. Soil is considered to be ultra-acid, extremely acid, very strongly acid, strongly acid, moderately acid, slightly acid, neutral, slightly alkaline, moderately alkaline, strongly alkaline, very strongly alkaline when the soil $\mathrm{pH}$ is < 3.5, 3.5-4.4, 4.5-5.0, 5.1-5.5, 5.6-6.0, 6.16.5, 6.6-7.3 7.4-7.8, 7.9-8.4, 8.5-9.0, >9.0 respectively (Soil Science Division Staff, 2017). The average soil $\mathrm{pH}$ of the study area was 8.31 therefore; the soil of the study area is generally considered to be moderately alkaline soil, except for the site Y15 of Dibag Tapa2 village where $\mathrm{pH}$ value for this site was 8.50 and considered to be strongly alkaline soil according to Soil Science Division Staff, 2017. Calcium carbonate $\left(\mathrm{CaCO}_{3}\right)$ average in the soil of the study area is $(31.05 \%)$, according to the classification of the calcareous soil of Gundalia, and Savalia (2001) which depend on the calcium carbonate proportion. The soil type of Y1, Y2, Y4, Y10, Y11, Y12, Y16, Y19 sites are highly calcareous soil and Y3, Y5, Y6, Y7, Y8, Y9, Y13, Y14, Y15, Y17, Y18, Y20 sites are strongly calcareous soil. Calcareous soils can be formed either as a result of weathering parent material (limestone) or due to the calcification process (Alloway, 2005). Average concentration of calcium sulfate $\left(\mathrm{CaSO}_{4} \cdot 2 \mathrm{H}_{2} \mathrm{O}\right)$ was $0.08 \%$ therefore; soil of study area is considered to be non-gypsiferous, except for the site Y14 of Dibag Tapa1 village where calcium sulfate concentration was $1.12 \%$, therefor; soil of this site is considered to be slightly gypsiferous depending on Barzanji (1973). OM can reduce the bioavailability and immobilize of heavy elements by retaining these elements, but increasing the amount of OM in the soil leads to the release of the elements into the soil solution (Sherene, 2010). and OM average in soil of study area was $1.25 \%$. Its low concentrations in the soil of the study area may be due to overgrazing and burning of farmlands (Al-Saady et al., 2016), traditional tillage (Barut and Celik, 2017) and drought climate (Göl, 2017). Salinity of the soil increases mobility of heavy metals (Mitchell et al., 2016). EC average of soil of the study area was $0.55 \mathrm{mmhos} / \mathrm{cm}$ and according to (Soil Science Division Staff, 2017) is non saline soil, where soils with electrical conductivity $(\mathrm{EC})(<2 \mathrm{mmhos} / \mathrm{cm})$ is a non-saline soil. The results of the size 
fraction analysis of soil samples showed that soil of the study area generally constitute of $44 \%$ silt, $32 \%$ sand, and 24\% clay, with a loam texture (USEPA, 1996). The clay percentage was the lowest percentage compared with the other soil parts of the study area. The heavy elements mobility in the soil is greatly influenced by the type of the soil texture, due to its relationship with adsorption surfaces for heavy elements in soil like oxides and clay, as the elements are held in clay soil more than sandy soil (Sherene, 2010).

Table 1. Different soil physiochemical properties of the study area

\begin{tabular}{ccccccccc}
\hline $\begin{array}{c}\text { Samples } \\
\text { No. }\end{array}$ & $\mathbf{p H}$ & $\begin{array}{c}\text { CaCO3 } \\
\text { \% }\end{array}$ & $\begin{array}{c}\text { CaSO4.2H2O } \\
\text { \% }\end{array}$ & $\begin{array}{c}\text { OM } \\
\text { \% }\end{array}$ & $\begin{array}{c}\text { EC } \\
\text { mmhos/cm }\end{array}$ & $\begin{array}{c}\text { Sand } \\
\text { \% }\end{array}$ & $\begin{array}{c}\text { Silt } \\
\text { \% }\end{array}$ & $\begin{array}{c}\text { Clay } \\
\text { \% }\end{array}$ \\
\hline Y1 & 8.38 & 25.80 & 0.16 & 1.37 & 1.15 & 6 & 50 & 44 \\
Y2 & 8.22 & 29.88 & 0.01 & 1.56 & 0.26 & 54 & 26 & 20 \\
Y3 & 8.09 & 33.04 & 0.02 & 1.08 & 0.24 & 8 & 55 & 37 \\
Y4 & 8.24 & 27.44 & 0.00 & 2.76 & 0.34 & 56 & 28 & 16 \\
Y5 & 8.33 & 30.96 & 0.04 & 0.67 & 0.44 & 60 & 28 & 12 \\
Y6 & 8.26 & 38.44 & 0.00 & 0.49 & 0.27 & 36 & 40 & 24 \\
Y7 & 8.27 & 33.44 & 0.00 & 1.08 & 0.36 & 54 & 30 & 16 \\
Y8 & 8.30 & 31.00 & 0.00 & 0.85 & 0.20 & 52 & 30 & 18 \\
Y9 & 8.30 & 35.64 & 0.00 & 0.51 & 0.25 & 11 & 71 & 18 \\
Y10 & 8.36 & 26.36 & 0.00 & 0.82 & 0.18 & 20 & 52 & 28 \\
Y11 & 8.24 & 27.24 & 0.00 & 1.73 & 0.31 & 28 & 50 & 22 \\
Y12 & 8.33 & 27.68 & 0.02 & 1.12 & 0.69 & 11 & 64 & 25 \\
Y13 & 8.37 & 31.48 & 0.01 & 1.50 & 0.72 & 54 & 32 & 14 \\
Y14 & 8.27 & 30.64 & 1.12 & 1.04 & 1.49 & 41 & 43 & 16 \\
Y15 & 8.50 & 31.12 & 0.00 & 1.22 & 0.51 & 50 & 28 & 22 \\
Y16 & 8.39 & 26.64 & 0.00 & 1.65 & 0.60 & 5 & 56 & 39 \\
Y17 & 8.42 & 38.40 & 0.06 & 1.68 & 0.81 & 13 & 54 & 33 \\
Y18 & 8.38 & 32.60 & 0.11 & 1.07 & 1.05 & 5 & 54 & 41 \\
Y19 & 8.34 & 27.48 & 0.09 & 1.63 & 0.88 & 38 & 42 & 20 \\
Y20 & 8.30 & 35.72 & 0.01 & 1.24 & 0.36 & 42 & 36 & 22 \\
Average & 8.31 & 31.05 & 0.08 & 1.25 & 0.55 & 32 & 44 & 24 \\
\hline & & & & & & & &
\end{tabular}

\subsection{Toxic Heavy Elements Concentration in Agricultural Soil and Wheat Grain}

The concentrations of toxic heavy elements increased in the following order $\mathrm{Ni}>\mathrm{Cr}>\mathrm{Pb}>\mathrm{As}>$ $\mathrm{Cd}>\mathrm{Hg}$ with rates of $107.49,73.54,9.20,6.78,0.23$ and $0.018 \mathrm{mg} / \mathrm{kg}$ respectively (Table 2). The rate of nickel was $107.49 \mathrm{mg} / \mathrm{kg}$ and its concentration in all studied sites exceeded its rate in earth's crust (56 $\mathrm{mg} / \mathrm{kg}$ ) (Wedepohl, 1995) and Canadian Agricultural Soil Quality Guidelines for Ni (45 mg/kg) (CCME, 2015). While the rate of As and Cd elements was $6.78,0.23 \mathrm{mg} / \mathrm{kg}$ respectively and their concentration exceeded its rate in earth's crust 1.7, $0.1 \mathrm{mg} / \mathrm{kg}$ respectively (Wedepohl, 1995). Cr rate was $73.54 \mathrm{mg} / \mathrm{kg}$ and its concentration exceeded its rate of the Canadian Agricultural Soil Quality Guidelines $(64 \mathrm{mg} / \mathrm{kg})$ (CCME, 1997). The reason of higher contents of $\mathrm{Ni}, \mathrm{As}, \mathrm{Cd}, \mathrm{Cr}$ elements could be related to vehicles emissions (De Silva, 2016), oil industries (Ahmed and Gulser, 2019) and fertilizers usage (Biney et al., 1994). In contrast, of $\mathrm{Pb}$ and $\mathrm{Hg}$ contents $(9.20,0.018 \mathrm{mg} / \mathrm{kg}$ respectively) did not exceed any of the earlier criteria. In comparison, toxic heavy metals in wheat grains increased in the following order $\mathrm{Cr}>$ $\mathrm{Ni}>\mathrm{Pb}>\mathrm{As}>\mathrm{Cd}>\mathrm{Hg}$ to $2.11>0.53>0.29>0.26>0.005>0.0003 \mathrm{mg} / \mathrm{kg}$ respectively (Table 3). 
Table 2. Concentrations of toxic heavy elements $(\mathrm{mg} / \mathrm{kg})$ in agricultural soil

\begin{tabular}{|c|c|c|c|c|c|c|}
\hline Samples No. & $\mathbf{P b}$ & $\mathbf{N i}$ & As & Cd & $\mathrm{Cr}$ & Hg \\
\hline $\mathrm{Y} 1$ & 11.35 & 124.5 & 7.1 & 0.24 & 81.5 & 0.061 \\
\hline Y2 & 11.79 & 110.7 & 7.0 & 0.29 & 76.8 & 0.018 \\
\hline Y3 & 8.76 & 108.5 & 7.6 & 0.27 & 76.8 & 0.019 \\
\hline Y4 & 9.31 & 98.6 & 6.1 & 0.29 & 69.3 & 0.010 \\
\hline Y5 & 10.00 & 106.0 & 6.6 & 0.17 & 69.6 & 0.024 \\
\hline Y6 & 8.45 & 95.9 & 6.6 & 0.26 & 74.3 & 0.011 \\
\hline Y7 & 8.31 & 90.5 & 6.7 & 0.25 & 65.2 & 0.019 \\
\hline Y8 & 8.37 & 99.2 & 7.4 & 0.23 & 69.6 & 0.024 \\
\hline Y9 & 7.65 & 93.8 & 6.3 & 0.20 & 66.9 & 0.010 \\
\hline Y10 & 9.90 & 126.5 & 7.3 & 0.24 & 81.2 & 0.022 \\
\hline Y11 & 10.07 & 128.0 & 7.1 & 0.24 & 85.7 & 0.006 \\
\hline Y12 & 8.50 & 99.9 & 6.4 & 0.21 & 66.1 & 0.013 \\
\hline Y13 & 8.68 & 116.3 & 7.1 & 0.22 & 73.7 & 0.011 \\
\hline Y14 & 9.01 & 95.7 & 7.0 & 0.15 & 65.2 & 0.010 \\
\hline Y15 & 8.33 & 95.1 & 7.4 & 0.29 & 73.0 & 0.018 \\
\hline Y16 & 9.65 & 117.9 & 6.2 & 0.23 & 77.9 & 0.023 \\
\hline Y17 & 7.90 & 97.5 & 6.4 & 0.27 & 69.0 & 0.019 \\
\hline Y18 & 9.73 & 123.3 & 6.2 & 0.18 & 77.3 & 0.016 \\
\hline Y19 & 9.19 & 124.8 & 6.5 & 0.23 & 80.6 & 0.020 \\
\hline Y20 & 9.09 & 97.2 & 6.7 & 0.25 & 71.1 & 0.008 \\
\hline Average & 9.20 & 107.49 & 6.78 & 0.23 & 73.54 & 0.018 \\
\hline Earth Crust ${ }^{a}$ & 14.8 & 56 & 1.7 & 0.1 & 126 & 0.04 \\
\hline $\begin{array}{l}\text { Canadian agricultural } \\
\text { soil quality guidelines }\end{array}$ & 70 & $45^{c}$ & 12 & 1.4 & 64 & 6.6 \\
\hline
\end{tabular}

Table 3. Concentrations of toxic heavy elements $(\mathrm{mg} / \mathrm{kg})$ in wheat grains

\begin{tabular}{ccccccc}
\hline $\begin{array}{c}\text { Wheat Samples No. / } \\
\text { Soil Samples No. }\end{array}$ & $\mathrm{Pb}$ & $\mathrm{Ni}$ & $\mathrm{As}$ & $\mathrm{Cd}$ & $\mathrm{Cr}$ & $\mathrm{Hg}$ \\
\hline G1/Y1 & 0.56 & 0.5 & 0.3 & 0.03 & 2.3 & 0.001 \\
G2/Y3 & 0.60 & 0.5 & 0.3 & $<0.01$ & 2.0 & $<0.001$ \\
G3/Y9 & 0.16 & 0.5 & 0.3 & $<0.01$ & 2.0 & $<0.001$ \\
G4/Y12 & 0.17 & 0.5 & 0.2 & $<0.01$ & 2.2 & $<0.001$ \\
G5/Y18 & 0.14 & 0.7 & 0.2 & 0.01 & 2.1 & $<0.001$ \\
G6/Y16 & 0.17 & 0.7 & 0.4 & $<0.01$ & 2.0 & 0.002 \\
G7/Y17 & 0.18 & 0.5 & 0.2 & $<0.01$ & 2.1 & $<0.001$ \\
G8/Y14 & 0.40 & 0.4 & 0.2 & $<0.01$ & 2.2 & $<0.001$ \\
Average & 0.29 & 0.53 & 0.26 & 0.005 & 2.11 & 0.0003 \\
\hline
\end{tabular}

\subsection{Soil Content of Toxic Elements Relationship with Oxides and Soil Physiochemical Properties}

Understanding the relationship between toxic heavy elements in soil (Table 2) and some major oxides (Table 4), as well as the physiochemical properties of soil in the study area can help to explain the behavior of these elements in the soil. Therefore, the data were subjected to the statistical analysis of the Pearson correlation coefficient using SPSS 22, Table 5. Positive correlation between $\mathrm{Pb}-\mathrm{Al}_{2} \mathrm{O}_{3}$ $(\mathrm{r}=0.753), \mathrm{Pb}_{-} \mathrm{Fe}_{2} \mathrm{O}_{3}(\mathrm{r}=0.720), \mathrm{Pb}-\mathrm{MnO}(\mathrm{r}=0.521), \mathrm{Ni}_{-}-\mathrm{Al}_{2} \mathrm{O}_{3}(\mathrm{r}=0.849)$ and $\mathrm{Ni}-\mathrm{Fe}_{2} \mathrm{O}_{3}(\mathrm{r}=0.906), \mathrm{Ni}-$ $\mathrm{MnO}(\mathrm{r}=0.626), \mathrm{Cr}_{-} \mathrm{Al}_{2} \mathrm{O}_{3}(\mathrm{r}=0.729)$ and $\mathrm{Cr}-\mathrm{Fe}_{2} \mathrm{O}_{3}(\mathrm{r}=0.787)$, may indicate to the adsorption of $(\mathrm{Pb}$, $\mathrm{Ni}, \mathrm{Cr})$ elements on the surface of these oxides. While a negative correlation between $\mathrm{Pb}-\mathrm{CaO}(\mathrm{r}=-$ $0.578), \mathrm{Ni}-\mathrm{CaO}(\mathrm{r}=-0.744), \mathrm{Cr}-\mathrm{CaO}(\mathrm{r}=-0.600), \mathrm{Pb}-\mathrm{CaCO}_{3}(\mathrm{r}=-0.586), \mathrm{Ni}-\mathrm{CaCO}_{3}(\mathrm{r}=-0.619)$ and $\mathrm{Cr}-$ $\mathrm{CaCO}_{3}(\mathrm{r}=-0.462)$ may indicate substitution of these elements with calcium in calcite in varying proportions (Kabata-Pendias, 2011), then forming the element carbonates. Oxides and clay minerals have a significant role in reducing heavy elements abundance and mobility in the aqueous solution due to their large surface areas, by ion exchange and adsorption mechanisms (Ugwu and Igbokwe, 2019). 
Table 4. Concentrations of major oxides (\%) in agricultural soil

\begin{tabular}{ccccc}
\hline Sample No. & $\mathbf{A l}_{\mathbf{2}} \mathbf{O}_{\mathbf{3}}$ & $\mathbf{F e}_{\mathbf{2}} \mathbf{O}_{\mathbf{3}}$ & $\mathbf{C a O}$ & $\mathbf{M n O}$ \\
\hline Y1 & 9.56 & 4.80 & 16.06 & 0.10 \\
Y2 & 9.42 & 4.78 & 16.84 & 0.09 \\
Y3 & 8.69 & 4.44 & 18.93 & 0.08 \\
Y4 & 8.89 & 4.48 & 17.18 & 0.09 \\
Y5 & 9.23 & 4.61 & 16.73 & 0.10 \\
Y6 & 8.36 & 4.23 & 19.38 & 0.08 \\
Y7 & 8.07 & 4.12 & 20.99 & 0.08 \\
Y8 & 8.23 & 4.27 & 20.08 & 0.08 \\
Y9 & 8.20 & 4.18 & 18.98 & 0.08 \\
Y10 & 9.58 & 4.86 & 17.00 & 0.09 \\
Y11 & 9.94 & 5.01 & 16.08 & 0.09 \\
Y12 & 8.62 & 4.41 & 17.52 & 0.09 \\
Y13 & 9.19 & 4.74 & 16.52 & 0.10 \\
Y14 & 9.06 & 4.41 & 18.81 & 0.09 \\
Y15 & 8.37 & 4.26 & 18.74 & 0.08 \\
Y16 & 9.26 & 4.69 & 16.57 & 0.09 \\
Y17 & 8.29 & 4.23 & 18.60 & 0.09 \\
Y18 & 8.87 & 4.53 & 18.44 & 0.09 \\
Y19 & 9.47 & 4.88 & 15.68 & 0.10 \\
Y20 & 8.06 & 4.13 & 21.24 & 0.08 \\
\hline
\end{tabular}

Table 5. Relationship between toxic heavy elements, major oxides, and soil physiochemical properties

\begin{tabular}{ccccccc}
\hline & $\mathbf{P b}$ & $\mathbf{N i}$ & $\mathbf{A s}$ & $\mathbf{C d}$ & $\mathbf{C r}$ & $\mathbf{H g}$ \\
\hline $\mathrm{Al}_{2} \mathrm{O}_{3}$ & $0.753^{* *}$ & $0.849^{* *}$ & 0.146 & -0.148 & $0.729^{* *}$ & 0.269 \\
$\mathrm{Fe}_{2} \mathrm{O}_{3}$ & $0.720^{* *}$ & $0.906^{* *}$ & 0.159 & -0.075 & $0.787^{* *}$ & 0.266 \\
$\mathrm{CaO}$ & $-0.578^{* *}$ & $-0.744^{* *}$ & 0.067 & 0.071 & $-0.600^{* *}$ & -0.291 \\
$\mathrm{MnO}$ & $0.521^{*}$ & $0.626^{* *}$ & -0.162 & -0.330 & 0.342 & 0.375 \\
$\mathrm{pH}$ & -0.101 & 0.105 & -0.180 & -0.112 & 0.014 & 0.27 \\
$\mathrm{CaCO}_{3}$ & $-0.586^{* *}$ & $-0.619^{* *}$ & -0.131 & 0.07 & $-0.462^{*}$ & -0.364 \\
$\mathrm{CaSO}_{4} \cdot 2 \mathrm{H}_{2} \mathrm{O}$ & 0.027 & -0.132 & 0.086 & $-0.548^{*}$ & -0.265 & -0.041 \\
$\mathrm{OM}$ & 0.257 & 0.212 & -0.245 & $0.453^{*}$ & 0.198 & -0.045 \\
$\mathrm{EC}$ & 0.118 & 0.179 & -0.176 & $-0.516^{*}$ & -0.048 & 0.284 \\
$\mathrm{Sand}$ & 0.003 & -0.353 & 0.183 & 0.146 & -0.311 & -0.267 \\
$\mathrm{Silt}$ & -0.191 & 0.217 & -0.257 & -0.300 & 0.127 & 0.032 \\
$\mathrm{Clay}$ & 0.264 & $0.447^{*}$ & -0.028 & 0.111 & $0.485^{*}$ & $0.525^{*}$ \\
\hline
\end{tabular}

** Correlation is significant at the 0.01 level (2-tailed), * Correlation is significant at the 0.05 level (2-tailed)

The positive correlation between Cd-OM ( $\mathrm{r}=0.453)$, indicates the adsorption of cadmium on the surface of organic matter and its binding with immobile forms (Sungur et al. 2014). Moreover, Cd$\mathrm{CaSO}_{4} .2 \mathrm{H}_{2} \mathrm{O}(\mathrm{r}=-0.548)$ and $\mathrm{Cd}-\mathrm{EC}(\mathrm{r}=-0.516)$ showed negative correlation. These two relationships may be attributed to the fact that $\mathrm{Cd}$ concentration in the soil of study area did not affect by soil salinity, as calcium sulfate (gypsum) is one of the salt types exist in the nature, and (Kadkhodaie et al. 2012) pointed out that the soil salinity increases $\mathrm{Cd}$ abundance in soil. The positive correlation between $\mathrm{Ni}$ Clay ( $r=0.447)$, Cr-Clay $(r=0.485)$ and Hg-Clay $(r=0.525)$, refers that these three elements are adsorbed on clay surfaces. No correlation was observed between the $\mathrm{pH}$ and soil content of toxic heavy elements, which may indicate that the elements availability were not affected by $\mathrm{pH}$, as well as Pearson correlation showed that arsenic was not associated with any of the oxides and soil physiochemical properties, which could indicate that the arsenic available to the wheat for absorption in the study area was not affected by the oxides or the physiochemical properties of the soil.

\subsection{Bioaccumulation of Toxic Heavy Elements in Wheat Grain}

Wheat was studied to understand the extent of the effectiveness of oxides and different soil physiochemical properties and its type in the retention of toxic heavy elements in the agricultural soil of 
the study area and reducing if not preventing their translocation to the plant, thus their bioaccumulation, as it is one of the most planted crops in the region. There are many processes that control heavy elements absorption from the soil by plants like oxidation and reduction reactions, deposition-dissolution and ionic exchange (Bajraktari et al. 2019). Heavy elements translocation and accumulation are influenced by species of the plant, elements bioavailability, soil composition (De Silva, 2016) and its physiochemical properties (Xiao-Rui et al. 2016). The transfer and bioaccumulation of toxic heavy elements from soil to wheat grain was studied using the bioaccumulation factor. Since the bioaccumulation factor $(\mathrm{BCF})$ represents the concentration of toxic elements in plant tissue to the concentration of toxic elements in the soil (Boussen et al. 2013).

$$
\mathrm{BCF}=\mathrm{C}_{\text {plant }} / \mathrm{C}_{\text {soil }}
$$

When BCF value is $\leq 1$ it refers that the heavy elements do not accumulate in the plant; whereas the BCF $>1$ indicates the accumulation of elements in the plant tissue (Liu et al., 2009). It turns out that the studied toxic heavy elements do not accumulate in wheat grains (Table 6), indicating the weak accumulation of toxic heavy elements in wheat grains despite their high concentrations in the soil. This may be because the bioaccumulation of elements $(\mathrm{Pb}, \mathrm{Ni}, \mathrm{As}, \mathrm{Cd}, \mathrm{Cr}$ and $\mathrm{Hg})$ in wheat grains is the least compared to other parts of the wheat plant (i.e. leaves, stems and roots) (Xiao-Rui et al., 2016).

Table 6. Bioaccumulation rates of toxic heavy elements in wheat grains

\begin{tabular}{ccccccc}
\hline Samples No. & Pb & Ni & As & Cd & Cr & Hg \\
\hline G1 & 0.049 & 0.004 & 0.042 & 0.125 & 0.028 & 0.016 \\
G2 & 0.068 & 0.005 & 0.039 & 0.000 & 0.026 & 0.000 \\
G3 & 0.021 & 0.005 & 0.048 & 0.000 & 0.029 & 0.000 \\
G4 & 0.020 & 0.005 & 0.031 & 0.000 & 0.033 & 0.000 \\
G5 & 0.014 & 0.006 & 0.032 & 0.056 & 0.027 & 0.000 \\
G6 & 0.018 & 0.006 & 0.065 & 0.000 & 0.026 & 0.087 \\
G7 & 0.023 & 0.005 & 0.031 & 0.000 & 0.030 & 0.000 \\
G8 & 0.044 & 0.004 & 0.029 & 0.000 & 0.034 & 0.000 \\
Average & 0.032 & 0.005 & 0.039 & 0.022 & 0.029 & 0.012 \\
\hline
\end{tabular}

The bioaccumulation of toxic heavy elements in general is relatively low as in the following order $\mathrm{As}>\mathrm{Pb}>\mathrm{Cr}>\mathrm{Cd}>\mathrm{Hg}>\mathrm{Ni}$ at $0.039>0.032>0.029>0.022>0.012>0.005$ respectively. However, there is a difference between the bioaccumulation rates of toxic heavy elements, and this may be due to the role of oxides and the physiochemical properties of the soil. It was observed that the bioaccumulation of arsenic is higher than the other studied elements, while it did not have the highest concentration among the studied elements in the soil, possibly due to the fact that the arsenic available to the wheat for absorption in the study area unlike other elements was not affected by any of the oxides and physiochemical properties soil as previously described in the results of the Pearson correlation. Although, the concentration of lead in soil was low in comparison to $\mathrm{Cr}$, In addition to the significant role of $\mathrm{CaCO}_{3}$ and major oxides in the retention of $\mathrm{Pb}$ and $\mathrm{Cr}$, beside $\mathrm{Cr}$ adsorption on clay surface. However, the bioaccumulation of lead was found to be higher than that of chromium. This may indicate that $\mathrm{Pb}$ ability to translocate and accumulate in wheat grains is higher than $\mathrm{Cr}$. While the soil of the study area is contaminated with $\mathrm{Cd}$, the bioaccumulation of $\mathrm{Cd}$ in wheat grain was not high, because soil type of study area (inorganic and non-saline soil) helped to reduce $\mathrm{Cd}$ bioaccumulation, (Karak et al., 2014) pointed that increasing quantity of OM in the soil could affect the cadmium mobility and toxicity in the soil through forming a mobile organic cadmium compounds. Also (Rinaudo et al., 1988) has reported that cadmium concentration increases with increasing gypsum proportion in soil. 
Although, nickel content in the studied soil samples is the highest, and the soil of study area is considered being contaminated with $\mathrm{Ni}$, but its bioaccumulation found to be the lowest compared to the rest of the studied elements. This could refer to the soil physiochemical properties $\left(\mathrm{CaCO}_{3}\right.$ and clay content) as well as $\mathrm{Fe}, \mathrm{Mn}$, and $\mathrm{Al}$ oxides affected $\mathrm{Ni}$ availability in the soil more than the other studied elements. The Hg low concentration in soil and its adsorption on clay surfaces as discussed previously caused $\mathrm{Hg}$ low bioaccumulation. Mercury content in the soil is affected by clay content, as its content increases with the increase in the percentage of clay, due to clay retaining mercury on its surface (Kongchum et al., 2011). Bioaccumulation of $\mathrm{Pb}$ and $\mathrm{Cr}$ were higher than $\mathrm{Ni}$ in wheat grain, although nickel concentration in soil was the highest, likely because of the stronger adsorption capacity of $\mathrm{CaCO}_{3}$ as well as $\mathrm{Fe}, \mathrm{Mn}$, and $\mathrm{Al}$ oxides for $\mathrm{Ni}$ than $\mathrm{Pb}$ and $\mathrm{Cr}$, which could be noticed from the high correlation values between $\mathrm{Ni}$ and this properties and oxides comparing to the $\mathrm{Pb}$ and $\mathrm{Cr}$ in soil. (Chaney et al. 2008) have mentioned that calcium element in the soil decreases nickel absorption by plants, and (Alloway, 2005) suggested that $\mathrm{Ca}^{+2}$ in calcium carbonate could be substitute by other elements. Which means that wheat plant of study area may absorbed the calcium instead of the elements $(\mathrm{Ni}, \mathrm{Cr}$ and $\mathrm{Pb})$. This may be due to the occurrence of substitution the calcium of the calcium carbonate in the soil of study area with $(\mathrm{Ni}, \mathrm{Cr}$ and $\mathrm{Pb})$ elements, which led to formation of $(\mathrm{Ni}, \mathrm{Cr}$ and $\mathrm{Pb})$ carbonate compounds, thus the release calcium into the soil solution.

\section{Conclusions}

High concentrations of $\mathrm{Ni}, \mathrm{As}$, and Cd elements in the studied soil samples showed that the soil is affected by these three elements as a result of human activities (vehicle emissions, oil industries, and fertilizer usage). The soil type of study area is medium alkaline, non-saline, calcareous, non-gypsiferous, inorganic and loam texture according to soil physiochemical properties. It was concluded that soil physiochemical properties and thus its type as well as the oxide content of the soil played an important role in reducing the bioaccumulation and concentration of $\mathrm{Pb}, \mathrm{Ni}, \mathrm{Cd}, \mathrm{Cr}$ and $\mathrm{Hg}$ elements in wheat grains except for arsenic. As for arsenic, it did not show any relationship with any of the soil physiochemical properties and oxides, indicating that its concentration in soil has been affected by only human activities that exist in the study area, leading to the higher bioaccumulation comparing with the other studied elements. This indicates two things: first, strong influence of oxides, soil type and its physiochemical properties on preventing or minimizing the translocation of $\mathrm{Pb}, \mathrm{Ni}, \mathrm{Cd}, \mathrm{Cr}$ and $\mathrm{Hg}$ elements into wheat grains which planted in contaminated soil, thus protect and preserve consumer health from being exposed to these toxic elements. Second, since the arsenic content in the soil of the study area was not affected by any of the oxides and the physiochemical properties of the soil, this means that if the concentration of arsenic in the soil was higher than its current concentration, it may cause a serious problem due to arsenic increased bioaccumulation in wheat grains. It became clear that wheat grains grown in the soil of the study area do not pose any potential risks regarding the soil-plant translocation mechanism of $\mathrm{Pb}, \mathrm{Ni}, \mathrm{Cd}, \mathrm{Cr}$ and $\mathrm{Hg}$ elements. Thus, the studied farmlands of Yaychi area currently are suitable for planting wheat crops regarding the concentration of toxic heavy elements and soil conditions.

\section{Acknowledgements}

Authors are very grateful to the Editor in Chief Prof. Dr. Salih M. Awadh, the Secretary of Journal Mr. Samir R. Hijab. and the Technical Editors for their great efforts and valuable comments.

\section{References}

Ahmed, A. N., Gulser, F., 2019. Industry caused heavy metal pollution in the soils of north-Iraq. Fresenius Environmental Bulletin 28(2A), 1057-1064. 
Alloway, B. J., 2005. Bioavailability of Elements in Soil. In: Selinus, O., Alloway, B. J., Centeno, J. A., Finkelman, R. B., Fuge, R., Lindh, U., and Smedley, P., (eds), Essentials of Medical Geology: Impacts of the Natural Environment on Public Health. Elsevier Academic Press, USA.

Al-Hamdani, J. A. J., Awadh, S. M., Ibrahim, O. S., 2016. Geochemical partitioning of heavy metals in the urban soil, Kirkuk, Iraq. Iraqi Geological Journal 39-49(1), 1-24.

Al-Jaberi, M. H., Al-Dabbas, M.A., Al-Khafaji, R., 2016. Assessment of heavy metals contamination and sediment quality in Shatt Al-Arab river, S Iraq. Iraqi Geological Journal 39-49(1), 88-97.

Al-Kadhimi, J. A., Sissakian, V.K., Deikran, D. B., and Fattah, A.S., 1996. Tectonic Map of Iraq, Scale 1:1000000, second ed. GEOSURV, Baghdad, Iraq.

Al-Saady, Y.I., Al-Tawash, B. S., and Al-Suhail, Q. A., 2016. Effects of land use and land cover on concentrations of heavy metals in surface soils of Lesser Zab River Basin, NE Iraq. Iraqi Journal of Science 57(2C), 1484-1503.

Bajraktari, D., Bauer, B., Kavrakovski, Z., Zeneli, L., 2019. Environmental pollution and heavy metals accumulation in Salix alba L. (Fam. Salicaceae), along the river stream of Sitnica. Agriculturae Conspectus Scientificus 84(1), 95-101.

Barut, Z. B., and Celik, I., 2017. Tillage effects on some soil physical properties in a semi-arid Mediterranean Region of Turkey. Chemical Engineering Transactions 58, 217-222.

Barzanji, A. F., 1973. Gypsiferous soils of Iraq. Ph.D. Thesis, University of Ghent, Belgium.

Biney, C., Amuzu, A.T., Calamari, D., Kaba, N., Mbome, I. L., Naeve, H., Ochumba, P. B. O., Osibanjo, O., Radegonde, V. and Saad, M.A.H., 1994. Review of heavy metals. In: Calamari, D., and Naeve, H. (eds), Review of pollution in the African aquatic environment, Report No. 25. Rome: FAO, 33-60.

Boussen, S., Soubrand, M., Bril, H., Ouerfelli, K., and Abdeljaouad, S., 2013. Transfer of lead, zinc and cadmium from mine tailings to wheat (Triticum aestivum) in carbonated Mediterranean (Northern Tunisia) soils. Geoderma, Elsevier B.V. 192, 227-236.

Carver, R. E., 1971. Procedures in sedimentary petrology. John Wiley\& Sons Incorporated, New York. CCME (Canadian Council of Ministers of the Environment), 1997. Recommended Canadian Soil Quality Guidelines. CCME, Winnipeg, Manitoba.

CCME (Canadian Council of Ministers of the Environment), 2015. Scientific Criteria Document for Canadian Soil Quality Guidelines for the Protection of Environmental and Human Health - Nickel. CCME, Winnipeg, Manitoba.

Chaney, R. L., Chen, K. Y., Li, Y. M., Angle, J. S., Baker, A. J. M., 2008. Effects of calcium on nickel tolerance and accumulation in Alyssum species and cabbage grown in nutrient solution. Plant and Soil, Springer 311(1-2), 131-140.

De Silva, M. S., 2016. Effect of Metal Vehicle Emissions on Physiochemical and Biological Properties of Aroadside Soil. M. Sc. Thesis, School of Engineering, College of Science, Engineering and Health, RMIT University, Melbourne, Australia.

Estefan, G., Sommer, R., Rayn, J., 2013. Methods of Soil, Plant, and Water Analysis: A manual for the West Asia and North Africa region, third ed. ICARDA (International Center for Agricultural Research in Dry Areas), Beirut.

Folk, R. L., 1974. Petrology of sedimentary rocks. Ham Phil, Austin.

Friis, R. H., 2012. Essentials of Environmental Health, second ed. Jones \& Bartlett Learning, LLC, USA.

Göl, C., 2017. Assessing the amount of soil organic matter and soil properties in high mountain forests in Central Anatolia and the effects of climate and altitude. Journal of Forest Science, 63(5):199-205.

Gundalia, J. D., Savalia, S. G., 2001. Genesis, Development and Classification of Calcareous Soils of Gujarat. In: Pasricha, N.S., Bansal, S.K., and Golakiya B.A. (eds), National Symposium on Balanced Nutrition of Groundnut and Other Field Crops Grown in Calcareous Soils of India. Junagadh, Gujarat.

Hu, B., Jia, X., Hu, J., Xu, D., Xia, F., Li, Y., 2017. Assessment of heavy metal pollution and health risks in the soil-planthuman system in the Yangtze river delta, China. International Journal of Environmental Research and Public Health 14(9), 1042.

Kabata-Pendias, A., 2011. Trace elements in soils and plants, fourth ed. CRC press, Taylor and Francis Group,LLC, Boca Raton.

Kadkhodaie, A., Kelich, S., Baghbani, A., 2012. Effects of salinity levels on heavy metals (Cd, $\mathrm{Pb}$ and $\mathrm{Ni}$ ) absorption by sunflower and sudangrass plants. Bulletin of Environment, Pharmacology and Life Sciences 1(12), 47-53.

Karak, T., Paul, R. K., Das, D. K., Boruah, R. K., Sonar, I., 2014. Thermodynamics of cadmium sorption on different soils of West Bengal, India. The Scientific World Journal.

Kongchum, M., Hudnall, W. H., Delaune, R. D., 2011. Relationship between sediment clay minerals and total mercury. Journal of Environmental Science and Health, Part A 46(5), 534-539.

Liu, W. X., Liu, J. W., Wu, M. Z., Li, Y., Zhao, Y., Li, S. R., 2009. Accumulation and translocation of toxic heavy metals in winter wheat (Triticum aestivum L.) growing in agricultural soil of Zhengzhou, China. Bulletin of environmental contamination and toxicology, Springer 82(3), 343-347.

Mitchell, K. N., Gómez, M. S. R., Barrera, A. L. G., Flores, L. Y., de la Torre, J. A. F., González, F. J. A., 2016. Evaluation of environmental risk of metal contaminated soils and sediments near mining sites in Aguascalientes, Mexico. Bulletin of Environmental Contamination and Toxicology 97(2), 216-224. 
Nagajyoti, P. C., Lee, K. D., Sreekanth, T. V. M., 2010. Heavy metals, occurrence and toxicity for plants: a review. Environmental Chemistry Letters 8(3), 199-216.

Richards, L. A., 1954. Diagnosis and improvement of saline and alkali soils. US Salinity Lab., US Department of Agriculture Handbook 60, California, USA.

Rinaudo, C., Frachini-Angela, M., Boistelle, R., 1988. Gypsum crystallization from cadmium-poisoned solutions. Journal of Crystal Growth, Elsevier, 89(2-3), 257-266.

Sherene, T., 2010. Mobility and transport of heavy metals in polluted soil environment. Biological Forum an International Journal 2(2), 112-121.

Sissakian, V. K., Fouad, S. F., 2012. Geological map of Iraq, scale 1:1000 000, fourth ed. Sheet No.1. GEOSURV, Baghdad, Iraq.

Soil Science Division Staff, 2017. Soil Survey Manual. United States Department of Agriculture Handbook No. 18.

Sungur, A., Soylak, M., Ozcan, H., 2014. Investigation of heavy metal mobility and availability by the BCR sequential extraction procedure: relationship between soil properties and heavy metals availability. Chemical Speciation and Bioavailability 26(4), 219-230.

Tokar, E. J., Boyd, W. A., Freedman, J. H., Waalkes, M. P., 2013. Toxic Effects of Metals. In: Klaassen, C. D., (ed), Casarett and Doull's Toxicology: The Basic Science of Poisons, eighth ed. McGraw-Hill Education, LLC, New York.

Ugwu, I. M., and Igbokwe, O. A., 2019. Sorption of Heavy Metals on Clay Minerals and Oxides: A Review. In: Edebali, S., (ed), Advanced Sorption Process Applications. Intech Open.

USEPA US Environmental Protection Agency., 1996. Soil Screening Guidance: User's Guide. second ed. Office of Emergency and Remedial Response, U.S. Environmental Protection Agency, Washington, DC 20460.

Walkley, A., 1947. A critical examination of a rapid method for determining organic carbon in soils-Effect of variations in digestion conditions and of inorganic soil constituents. Soil Science LWW 63(4), 251-264.

Wedepohl, K. H., 1995. The composition of the continental crust. Geochimica et cosmochimica Acta, Elsevier Science Ltd 59(7), 1217-1232.

Whitehead, D. C., 1973. The Sorption of Iodide by Soils as influenced by equilibrium conditions and soil properties. Journal of the Science of Food and Agriculture 24(5), 547-556.

Xiao-Rui, W., Sheng-Lu, Z., Shao-Hua, W., 2016. Accumulation of heavy metals in different parts of wheat plant from the Yangtze river Delta, China. International Journal of Agriculture and Biology 18(6), 1242-1248. 